\title{
CALCULATION OF LOCATION VALUE TO DETERMINE THE LOCATION OF A NEW TERMINAL IN SINGKAWANG CITY
}

\author{
Ardellia Cesarine Sutrisno, ${ }^{1}$ Heskey Fahrevi Ramadhan, ${ }^{2}$ \\ Muhammad Raihan Iswahyudi, ${ }^{3}$ Putri Nur Mauliah ${ }^{4}$ \\ dan Venansius Hugo Harwanda ${ }^{5}$ \\ ${ }^{1}$ DIII Study Program Road Transportation Management, Land Transport \\ Academy, Raya Setu Street No. 89 Bekasi District, 17520, Indonesia \\ ${ }^{2}$ Land Transport Academy, Raya Setu Street No. 89 Bekasi District, 17520, \\ Indonesia \\ *raihaniswahyudi5@gmail.com \\ Manuscript travel history: \\ Received: November $27^{\text {th }} 2020$; revised: December $11^{\text {st }} 2020$; approved: \\ December $18^{\text {th }} 2020$ \\ published online: January $13^{\text {rd }} 2021$
}

\begin{abstract}
The terminal is a road transportation infrastructure that is used for loading and unloading of goods, as well as the arrival and departure of public vehicles. The existence of a terminal is very important in determining the level of performance of public transport services in an area. The role of terminals is very important as infrastructure that can attract public interest in using public transportation. Determining the location of the terminal is also very important to enter as an accessibility factor that can reach the wider community of Singkawang City. This study aims to see which alternative locations are most suitable for building type B terminals using the Composite Performance Index (CPI) method. To analyze the location value required data such as road capacity data from road inventory survey, traffic volume data from traffic calculation survey results, and speed data from a moving car observer survey.
\end{abstract}

Keywords : Terminals, Infrastructure, Accessibility

\section{Preliminary}

Along with the development of transportation in Singkawang City, which is one of the big cities in West Kalimantan, of course it has a very large need for supporting transportation facilities and infrastructure.

With the increase in transportation activities, the consequence is the need to build a terminal that is able to accommodate all the activities of the community in fulfilling the need for movement from one place to another. Singkawang City has 2 terminals, namely the Singkawang terminal located on Station road, West Singkawang and the Bengkayang terminal located on Jalan Hulu, Singkawang City. The Singkawang Terminal itself is a type B passenger terminal that serves public transportation for inter-city transportation within the province, city transportation and / or rural 
transportation. But in fact this terminal is not operating optimally due to the lack of public interest in using public transportation. In addition, not many public transports enter this terminal and mostly attract passengers around the terminal area or on the side of the road.

This is considered easier for the community than having to go to the terminal considering the accessibility factor, namely the location of the terminal which is quite far away which can be a problem for the community to go to the terminal itself.

Based on KM No.31 Th.1995, the ideal condition of a public transport terminal must be equipped with facilities inside, either main or supporting facilities, so that vehicles entering the terminal area can be more orderly and comply with the signs that have been provided. The main facilities in a terminal are public transportation departure routes, public transportation arrival routes, public transportation parking lots, terminal office buildings, passenger waiting areas, control towers, ticket sales counters, signposts and information boards, and parking lots for taxi-type vehicles. .

The role of terminals is very important as infrastructure that can attract people to use public transportation. With a terminal that supports passenger needs, the public will be more interested in taking public transportation. Determining the location of the terminal is also very important to pay attention to as one of the accessibility factors that can reach the wider community of Singkawang City. The purpose of this location analysis is to provide an overview of the existing and problems in the terminal as well as recommendations for determining the location of the terminal construction in Singkawang City. This study aims to determine the existing conditions and problems in the Singkawang City terminal, determine the location based on the Composite Performance Index (CPI) method.

\section{Research Methods}

In research, data is needed, namely primary data and secondary data. Primary data required is inventory data of proposed terminal locations and traffic performance data around the location. And the secondary data are Singkawang City RTRW data, Singkawang City Land Use Map, Road Network Map. The required traffic performance data around the location is road capacity data obtained from road inventory surveys, traffic volume data obtained from traffic counting surveys, and speed data obtained from moving car observer surveys. In the analysis of location selection, the method uses 
the Composite Performance Index (CPI) method. In using the Composite Performance Index method, a ranking is carried out based on 4 performance criteria, namely the analysis of road segment performance criteria, accessibility criteria analysis, environmental sustainability criteria analysis, and initial investment cost criteria analysis. After the four performance criteria are totaled and ranked, the location with the highest score is the selected location.

\section{Results and Discussion}

There are 2 existing terminals in Singkawang City, namely Singkawang Terminal and Bengkayang Terminal. However, the two terminals have not been able to operate optimally. In determining the alternative location of the terminal, 3 alternative locations were given and each location was assessed based on the performance analysis of the road section performance criteria, accessibility criteria, environmental sustainability criteria and initial investment cost criteria. The four criteria are ranked using the Composite Performance Index (CPI) method.

In the Road Section Criteria Analysis, the choice of terminal location must consider traffic density and road capacity. The parameters assessed are road capacity, v / c ratio, speed, and road occupancy. And the result of the 3 alternative locations, location number 2 reached the highest score with a value of 423.53 . 
Table 1. Traffic Performance Criteria

\begin{tabular}{|c|c|c|c|c|c|c|c|}
\hline \multicolumn{8}{|c|}{ Traffic Performance Criteria } \\
\hline \multirow{3}{*}{ Parameter } & \multicolumn{6}{|c|}{ Alternative } & \multirow{3}{*}{ Information } \\
\hline & \multicolumn{2}{|c|}{ Alternative 1} & \multicolumn{2}{|c|}{ Alternative 2} & \multicolumn{2}{|c|}{ Alternative 3} & \\
\hline & Value & $\begin{array}{c}\text { Value } \\
\text { Transformation }\end{array}$ & Value & $\begin{array}{c}\text { Value } \\
\text { Transformation }\end{array}$ & Value & $\begin{array}{c}\text { Value } \\
\text { Transformation }\end{array}$ & \\
\hline Capacity & 1147 & 100 & 1305 & 113,77 & 1305 & 113,77 & TREND (+) \\
\hline V/C Ratio & 0,56 & 87,5 & 0,49 & 100 & 0,59 & 83,05 & TREND (-) \\
\hline Speed & 42,37 & 117,19 & 39,71 & 109,75 & 36,18 & 100 & $\begin{array}{c}\text { TREND } \\
(+)\end{array}$ \\
\hline $\begin{array}{c}\text { Road } \\
\text { Occupancy }\end{array}$ & 0,49 & 87,75 & 0,43 & 100 & 0,51 & 84,31 & TREND (-) \\
\hline Total & 1190,42 & 392,36 & 1345,63 & 423,53 & 1342,28 & 381,14 & \\
\hline
\end{tabular}


In the Analysis of Accessibility Criteria, the location of the terminal must have good accessibility to modal shift nodes, trade locations and city centers. And of the 3 alternative locations, the location that got the highest score was location number 2 with a score of 300

Table 2. Accessibility Criteria

\begin{tabular}{|c|c|c|c|c|c|c|c|}
\hline \multicolumn{8}{|c|}{ Accessibility Criteria } \\
\hline \multirow[b]{3}{*}{ Parameter } & \multicolumn{6}{|c|}{ Alternative } & \multirow[b]{3}{*}{$\begin{array}{c}\text { Informatio } \\
\mathrm{n}\end{array}$} \\
\hline & \multicolumn{2}{|c|}{ Alternative 1} & \multicolumn{2}{|c|}{ Alternative 2} & \multicolumn{2}{|c|}{ Alternative 3} & \\
\hline & Value & $\begin{array}{c}\text { Value } \\
\text { Transformatio } \\
\mathrm{n}\end{array}$ & Value & $\begin{array}{c}\text { Value } \\
\text { Transformation }\end{array}$ & Value & $\begin{array}{c}\text { Value } \\
\text { Transformatio } \\
\mathrm{n}\end{array}$ & \\
\hline $\begin{array}{l}\text { Distance To } \\
\text { The } \\
\text { Displacement } \\
\text { Node } \\
\text { ( Terminal } \\
\text { Pasiran ) }(\mathrm{Km})\end{array}$ & 2,42 & 98,35 & 2,38 & 100,00 & 2,79 & 85,30 & TREND (-) \\
\hline $\begin{array}{l}\text { Distance To } \\
\text { Trade } \\
\text { Locations } \\
\text { ( Hongkong } \\
\text { Market) }(\mathrm{Km})\end{array}$ & 2,92 & 95,55 & 2,79 & 100,00 & 3,29 & 84,80 & TREND (-) \\
\hline $\begin{array}{l}\text { Distance To } \\
\text { City Center } \\
\text { Vihara Tri } \\
\text { Dharma Bumi } \\
\text { Raya) }(\mathrm{Km})\end{array}$ & 2,61 & 98,08 & 2,56 & 100,00 & 3,00 & 85,33 & TREND (-) \\
\hline Total & 7,95 & 291,98 & 7,73 & 300,00 & 9,08 & 255,44 & \\
\hline
\end{tabular}


In the Environmental Sustainability Analysis, the environment required as an alternative location must not disturb the surrounding environment and the location must not be prone to pollution, not disturb the environment, not prone to noise and not prone to flooding. Of the 3 alternative locations, locations 2 and 3 get the same score, namely 550 .

Table 3. Environmental Sustainability Criteria

\begin{tabular}{|c|c|c|c|c|c|c|c|}
\hline \multicolumn{8}{|c|}{ Environmental Sustainability Criteria } \\
\hline \multirow{3}{*}{ Parameter } & \multicolumn{6}{|c|}{ Alternative } & \multirow{3}{*}{ Information } \\
\hline & \multicolumn{2}{|c|}{ Alternative 1} & \multicolumn{2}{|c|}{ Alternative 2} & \multicolumn{2}{|c|}{ Alternative 3} & \\
\hline & Value & $\begin{array}{c}\text { Value } \\
\text { Transformation }\end{array}$ & Value & $\begin{array}{c}\text { Value } \\
\text { Transformation }\end{array}$ & Value & $\begin{array}{c}\text { Value } \\
\text { Transformation }\end{array}$ & \\
\hline $\begin{array}{c}\text { Do Not } \\
\text { Disturb The } \\
\text { Surrounding } \\
\text { Environment }\end{array}$ & 2 & 100 & 2 & 100 & 2 & 100 & $\begin{array}{l}\text { TREND } \\
(+)\end{array}$ \\
\hline $\begin{array}{c}\text { Not Prone } \\
\text { To Pollution }\end{array}$ & 2 & 100 & 3 & 150 & 3 & 150 & $\begin{array}{c}\text { TREND } \\
(+)\end{array}$ \\
\hline $\begin{array}{l}\text { Not Prone } \\
\text { To Noise }\end{array}$ & 2 & 100 & 3 & 150 & 3 & 150 & $\begin{array}{l}\text { TREND } \\
(+)\end{array}$ \\
\hline $\begin{array}{c}\text { Not Prone } \\
\text { To Flooding }\end{array}$ & 3 & 150 & 3 & 150 & 3 & 150 & $\begin{array}{l}\text { TREND } \\
(+)\end{array}$ \\
\hline Total & 9 & 450 & 11 & 550 & 11 & 550 & \\
\hline
\end{tabular}


And in the last criteria analysis, namely Initial Investment Cost Criteria Analysis, it is expected that in the construction of the terminal costs incurred can be reduced to a minimum. And of the 3 locations, location number 1 gets the highest score with a value of 100 .

Table 4. Initial Investment Cost Criteria

\begin{tabular}{|c|c|c|c|c|c|c|c|}
\hline \multicolumn{8}{|c|}{ Initial Investment Cost Criteria } \\
\hline \multirow{3}{*}{ Parameter } & \multicolumn{6}{|c|}{ Alternative } & \multirow{3}{*}{ Information } \\
\hline & \multicolumn{2}{|c|}{ Alternative 1} & \multicolumn{2}{|c|}{ Alternative 2} & \multicolumn{2}{|c|}{ Alternative 3} & \\
\hline & Value & $\begin{array}{c}\text { Value } \\
\text { Transformation }\end{array}$ & Value & $\begin{array}{c}\text { Value } \\
\text { Transformation }\end{array}$ & Value & $\begin{array}{c}\text { Value } \\
\text { Transformation }\end{array}$ & \\
\hline $\begin{array}{c}\text { The land } \\
\text { price (per } \\
1 \mathrm{~m}^{2} \text { ) } \\
(\mathrm{Rp})\end{array}$ & 7000000 & 100 & 10000000 & 70 & 10000000 & 70 & TREND (-) \\
\hline Total & 7000000 & 100 & 10000000 & 70 & 10000000 & 70 & \\
\hline
\end{tabular}


From the four analysis criteria above. Then the four results are totaled and the following results are obtained

Table 5. The Sum of The Four Criteria

\begin{tabular}{|c|c|c|c|c|c|c|c|}
\hline \multirow[b]{2}{*}{ Parameter } & \multirow[b]{2}{*}{ Bobot } & \multicolumn{2}{|c|}{ Location 1} & \multicolumn{2}{|c|}{ Location 2} & \multicolumn{2}{|c|}{ Location 3} \\
\hline & & $\begin{array}{c}\text { Value } \\
\text { Transformation }\end{array}$ & $\begin{array}{c}\text { Location } \\
\text { Value }\end{array}$ & $\begin{array}{c}\text { Value } \\
\text { Transformation }\end{array}$ & $\begin{array}{c}\text { Location } \\
\text { Value }\end{array}$ & $\begin{array}{c}\text { Value } \\
\text { Transformation }\end{array}$ & $\begin{array}{c}\text { Location } \\
\text { Value }\end{array}$ \\
\hline $\begin{array}{l}\text { Road Section } \\
\text { Performance } \\
\text { Criteria }\end{array}$ & 0,32 & 392,37 & 125,55 & 423,54 & 135,53 & 381,14 & 121,97 \\
\hline $\begin{array}{l}\text { Accessibility } \\
\text { Criteria }\end{array}$ & 0,26 & 291,98 & 75,91 & 300 & 78 & 255,43 & 66,42 \\
\hline $\begin{array}{c}\text { Environmental } \\
\text { Sustainability } \\
\text { Criteria }\end{array}$ & 0,22 & 450 & 99 & 550 & 121 & 550 & 121 \\
\hline $\begin{array}{c}\text { Initial } \\
\text { Investment } \\
\text { Cost Criteria }\end{array}$ & 0,2 & 100 & 20 & 70 & 14 & 70 & 14 \\
\hline Total & 1 & 1234,34 & 320,47 & 1343,53 & 348,53 & 1256,58 & 323,38 \\
\hline Rangking & & 3 & & 1 & & 2 & \\
\hline
\end{tabular}

From the results above, it can be seen that location number 2 gets the highest score after adding the four criteria. Location number 2 is located on Jalan Ahmad Yani which in the 2013-2032 RTRW of Singkawang City it is explained that the road will later become a Secondary Arterial Road which will connect Singkawang with Pontianak and Singkawang with Sambas. Therefore location number 2 is suitable for building Type B terminals.

\section{Conclusion}

From the results of the analysis that has been carried out, recommendations can be taken for determining the location of the terminal by selecting from several alternatives. The alternative location that has the highest ranking is the most appropriate location for the construction location of the type B terminal in Singkawang City. From the weighting results using the Composite Performance Index (CPI) method, the second alternative can be used. Because from the ranking results, this second alternative is the top ranking. The construction of terminals in the selected locations is expected to increase the mobility of the people of Singkawang City and reduce the use of private vehicles in Singkawang City and the community to switch to using public transportation 


\section{Thank-you note}

We would like to extend our gratitude to all parties, both parents, friends who have always helped when working on this report. To Mr. Hindro Surahmat, ATD, M.Si as Director of the Land Transport Academy, Mr. Rachmat Sadili, M.T. . To Mr DR. I Made Suraharta, MT as a lecturer in the Integration Project course

\section{Reference}

Morlok, Edward K, (1978), "Pengantar Teknik dan Perencanaan Transportasi”, University of Pennsyvania

Abubakar dkk, 1995, Sistem Transportasi Kota, Jakarta : Direktorat Jendral Perhubungan Darat.

Warpani, Suwardjoko. 1990. Merencanakan Sistem Perangkutan. Bandung : Penerbit ITB.

Peraturan Menteri, R. I. (2015). No. 132 Tahun 2015. Tentang Penyelenggaraan Terminal Penumpang Angkutan Jalan

Peraturan Pemerintah, R. I. (2013). No. 79 Tahun 2013. Tentang Jaringan Lalu Lintas dan Angkutan Jalan

Fisu, A. A. (2018). ANALISIS LOKASI PADA PERENCANAAN TERMINAL TOPOYO MAMUJU TENGAH. PENA TEKNIK: Jurnal Ilmiah Ilmu-Ilmu Teknik, 3(1), 1-12.

Untu, V. M. G., Sendow, T. K., \& Manoppo, M. R. (2018). Perencanaan Terminal Angkutan Darat di Kecamatan Ratahan. Jurnal Sipil Statik, 6(1).

Kandou, C. T., Pandey, S. V., \& Kaseke, O. H. (2018). Perencanaan Terminal Penumpang Angkutan Jalan Tipe B di Kecamatan Tomohon Selatan Kota Tomohon. Jurnal Sipil Statik, 7(1).

Mintarsih, R., \& Sardjito, S. (2019). Penentuan Lokasi Terminal Angkutan Umum Tipe C di Kecamatan Bangil Kabupaten Pasuruan. Jurnal Teknik ITS, 8(1), E43-E47. 